\title{
Kajian Ship-To-Ship Transfer pada LNG Carrier
}

\author{
Kriyo Sambodho1, Aries Sulisetyono2, AA Masroeri2 \& Putri Dyah Setyorini3 \\ 1Dosen Jurusan Teknik Kelautan, Fakultas Teknologi Kelautan, Institut Teknologi Sepuluh Nopember \\ 2Dosen Jurusan Teknik Perkapalan, Fakultas Teknologi Kelautan, Institut Teknologi Sepuluh Nopember (ITS) \\ Surabaya Jl. Arif Rahman Hakim, Sukolilo, Surabaya Indonesia \\ 3Teknik Sistem Pengendalian dan Kelautan, Program Pascasarjana Teknologi Kelautan, ITS Surabaya \\ dhodhott@yahoo.com
}

\begin{abstract}
Abstrak
Studi ini membahas tentang kajian ship-to-ship sebagai bagian dari rantai pasok liquified natural gas (LNG) untuk kebutuhan pembangkit listrik yang tersebar di Indonesia Bagian Timur (IBT). Keinginan pemerintah untuk memanfaatkan gas bumi dalam bentuk LNG sebagai bahan bakar alternatif pada pembangkit listrik yang telah ada maupun pembangkit yang telah ada di IBT memerlukan sarana dan prasarana berupa stasiun penerima maupun kapal-kapal LNG skala kecil. Salah satu kendala yang dihadapi untuk mendistribusikan gas dari sumber LNG ke pembangkit-pembangkit adalah LNG yang akan diambil dari kilang hanya dapat dilakukan oleh kapal besar karena fasilitas jetty yang pada awalnya memang didesain hanya dapat menerima kapal berukuran besar. Metode yang diusulkan pada studi ini adalah LNG diambil oleh kapal LNG berukuran besar yang dapat dilayani oleh jetty yang kemudian akan ditransfer ke kapal LNG yang berukuran kecil (small $L N G$ vessel) melalui konsep ship-to-ship (STS) transfer. STS direncanakan dilakukan dimana $L N G$ carrier berukuran besar ditambatkan dengan sistem penambatan tunggal, kemudian small $L N G$ vessel berlabuh di sisi kapal LNG besar dengan bertambat pada 4 tali tambat. Pada dasarnya kajian STS ini terdiri dari dua tahap diantaranya adalah pemilihan lokasi STS dan analisa motion pada saat STS dilakukan. Ada 4 lokasi yang dipertimbangkan sebagai lokasi STS diantaranya adalah Fakfak, Manokwari, Namlea, dan Halmahera. Pada studi ini, kapal LNG ukuran $155.000 \mathrm{~m}^{3}$ dan shuttle LNG vessel ukuran $3000 \mathrm{~m}^{3}$ adalah objek dalam kajian STS pada studi ini. Analisa terhadap gerakan yang mungkin terjadi saat proses STS dilakukan dengan bantuan perangkat lunak MOSES. Teknik prediksi tiga dimensi (three-dimensional prediction technique) digunakan pada studi ini untuk memperkirakan floating body motions dalam short-crested seaway. Berdasarkan data lingkungan mengacu pada metocean data yang terdiri dari data angin, gelombang, dan arus, Fakfak terpilih sebagai lokasi terbaik untuk dilakukannya STS transfer dan hasil simulasi mendapatkan bahwa STS transfer di Fakfak aman untuk dilakukan selama proses STS transfer dilakukan pada tinggi gelombang $2 \mathrm{~m}$.

Kata kunci: LNG Carrier, Pemilihan Lokasi, Ship to Ship Transfer (STS), Three-Dimensional Prediction Technique
\end{abstract}

\section{PENDAhUluaN}

Gas bumi mempunyai peran yang sangat penting dalam pembangunan nasional, yaitu sebagai sumber energi, bahan baku dalam negeri. Oleh karena itu pemanfaatan gas alam sebagai sumber energi pembangkit tenaga listrik sangat sesuai dalam mengatasi krisis tenaga listrik yang terjadi di beberapa wilayah di Indonesia. Kebijakan pemerintah mengenai pemanfaatan sumber daya energi yang ada sangat penting guna pemenuhan kebutuhan sumber energi dalam negeri. Beberapa diantaranya adalah Peraturan Pemerintah No. 55/2009 dimana pada kebijakan ini dibahas mengenai alokasi gas bumi sebesar 25\% dari hasil produksi, berikutnya Peraturan Menteri ESDM No. 19/2009 dan No. 3/2010 mengenai infrastruktur bagi pemanfaatan sumber energi gas dan alokasi bagi kebutuhan domestic [1]. Dengan adanya beberapa kebijakan tersebut maka pemanfaatan gas bumi sebagai sumber energi pembangkit listrik dapat dilakukan secara optimal.

Beberapa pembangkit di wilayah Indonesia Bagian Timur (IBT) direncanakan akan dibangun dengan memanfaatkan bahan bakar gas. Namun, terdapat kendala yang harus dihadapi ketika perusahaan minyak dan gas berencana untuk memasok gas dalam bentuk LNG ke pembangkit yang lokasinya tersebar di wilayah IBT. Salah satu kendala tersebut yaitu pada transportasi LNG dari kilang menuju ke pembangkit, LNG hanya bisa diambil oleh kapal besar karena dimensi jetty yang pada dasarnya didesain hanya untuk dapat menerima kapal LNG berukuran besar. Metode yang diusulkan untuk membantu distribusi LNG dari kilang ke pembangkit-pembangkit ini adalah Kapal LNG yang berukuran besar digunakan untuk memuat LNG dari kilang yang kemudian akan di transfer ke shuttle $L N G$ vessel yang selanjutnya shuttle LNG vessel ini akan mendistribusikan LNG tiap-tiap pembangkit. Pada studi ini, ada empat lokasi yang dipertimbangkan untuk dijadikan lokasi STS LNG transfer yaitu: Fakfak, Manokwari, Namlea, dan Halmahera. Adapun lokasi dari keempat alternatif lokasi STS dapat dilihat pada Gambar 1. Sedangkan objek STS yang dijadikan kajian pada studi ini adalah kapal LNG ukuran 155000 $\mathrm{m}^{3}$ dengan shuttle LNG vessel ukuran $3000 \mathrm{~m}^{3}$. 


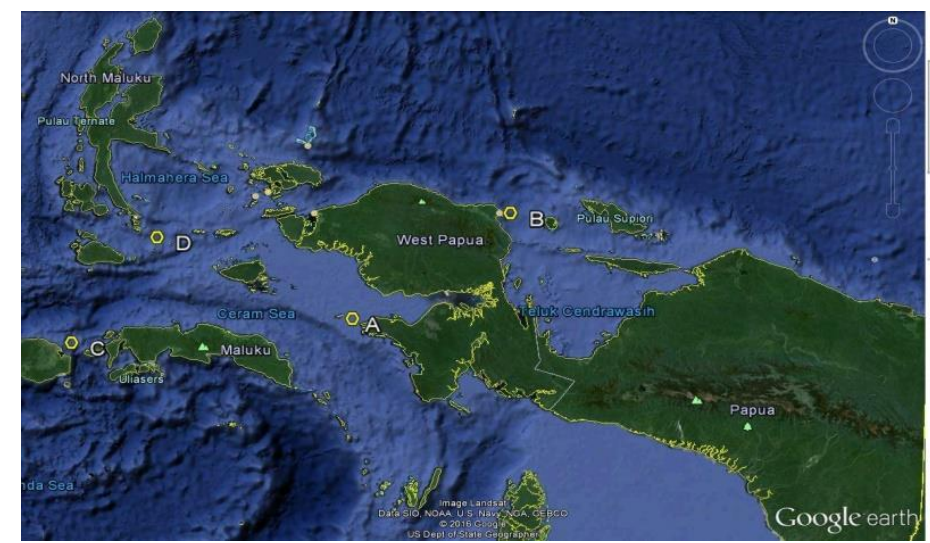

Gambar 1. Rencana lokasi STS LNG transfer

\section{KONDISI LINGKUNGAN SEBAGAI DASAR PEMILIHAN LOKASI STS TRASFER}

Data lingkungan memegang peranan yang sangat penting dalam pemilihan lokasi dimana STS transfer akan dilakukan. Data-data yang dibutuhkan diantaranya adalah kondisi batimetri, kecepatan dan arah arus, tinggi dan periode gelombang, serta kecepatan dan arah angin. Berikut ini akan diberikan hasil kajian pemilihan lokasi STS LNG transfer mengacu pada lingkungan.

\subsection{Kondisi Batimetri}

Pada studi ini data batimetri diperoleh melalui data Navionic dan kondisi batimetri ini ditujukan untuk pemilihan dan perencanaan lokasi STS LNG transfer. Pada Gambar 2 memperlihatkan kondisi batimetri yang ada di wilayah Fakfak, Manokwari, Namlea, dan Halmahera. Berdasarkan data batimetri tersebut, Fakfak memiliki variasi kedalaman berkisar antara 50-70 m. Sedangkan ketiga alternatif lokasi lainnya memiliki kedalaman lebih dari $500 \mathrm{~m}$.

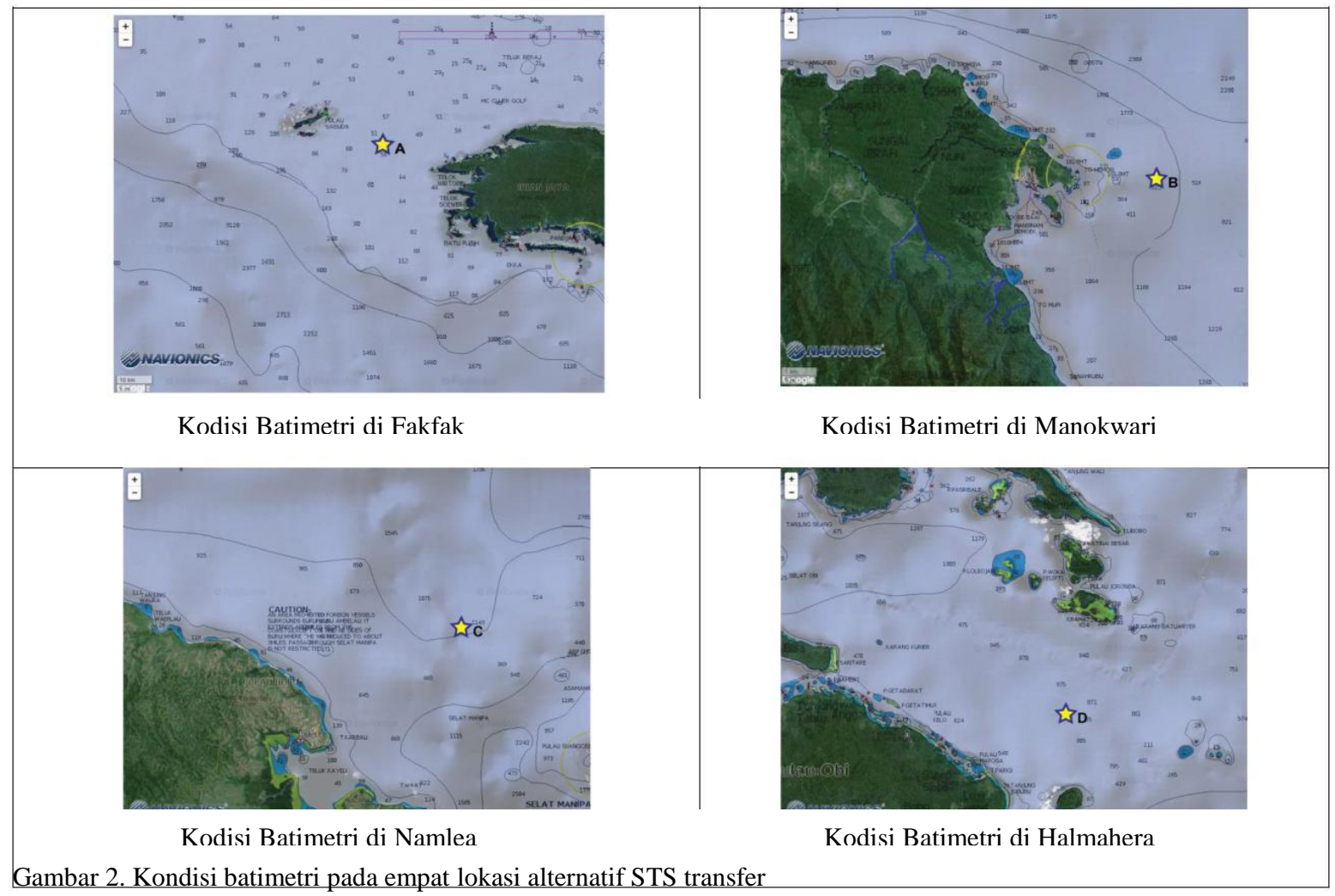

Kondisi batimetri atau kedalaman perairan ini menjadi sangat penting karena digunakan untuk menentukan sistem penambatan (mooring system) yang akan digunakan pada lokasi STS LNG transfer. Skenario penambatan yang diusulkan pada studi STS transfer ini adalah sebagai berikut: (i) Kapal besar melakukan penambatan di lokasi, (ii) shuttle LNG vessel datang kemudian bersandar di sisi kapal besar, (iii) shuttle LNG vessel ditambatkan ke kapal besar. Di wilayah yang memiliki perairan yang dalam, pemilihan sistem mooring itu sendiri adalah subjek yang menantang dalam eksplorasi lepas pantai. Struktur yang ditambatkan akan berpotensi terkena berbagai gangguan lingkungan yang memiliki karakteristik sebagai sistem dinamis dengan frekuensi eksitasi yang rendah dan tinggi. Gaya eksitasi merupakan hasil dari angin, gelombang dan arus 
yang bekerja pada pada sistem. Sedangkan gaya reaksi adalah kombinasi dari gaya akiat pertambahan massa (added mass forces), gaya akibat wave drift damping, gaya viskos, dan gaya akibat kombinasi gaya yang dipindahkan dan gaya damping akibat interaksi antara tali tambat dan riser. Aspek-aspek tersebutlah yang membangun kompleksitas sistem mooring pada laut dalam.

Dalam hal penambatan pada laut dalam, persyaratan yang umum dilakukan adalah mengacu pada "ABS Rules for Building and Classing Steel Vessel" yang meliputi aturan mengenai penambatan sementara (temporary mooring) untuk kapal di pelabuhan dan perairan yang terlindung (sheltered water) sampai dengan kedalaman $64 \mathrm{~m}$. Peraturan ini juga mengatur persyaratan penambatan sementara untuk kapal diluar area pelabuhan atau pada perairan yang terlindung sampai dengan kedalaman $120 \mathrm{~m}$. Secara umum aturan ini juga dapat digunakan untuk kondisi perairan yang memiliki kecepatan arus sampai dengan 1,54 m/s, kecepatan angin $14 \mathrm{~m} / \mathrm{s}$, dan amplitudo gelombang $3 \mathrm{~m}$. Berdasarkan data batimetri, kedalaman air di lokasi yang diusulkan untuk lokasi B, C dan D memiliki kedalaman lebih dari $500 \mathrm{~m}$. Pada kondisi ini, harus dipertimbangkan untuk menggunakan sistem mooring lain bukan sistem penambatan konvensional (conventional anchoring system). Dapat dikatakan bahwa dengan mempertimbangkan sistem penambatan konvensional, lokasi terbaik untuk STS LNG transfer adalah di lokasi A (Fakfak).

\subsection{Kondisi Arus Permukaan (Ocean Surface Current)}

Data arus permukaan laut diperoleh dari Ocean Surface Current Analysis Realtime -OSCAR [2]. Pada studi ini data arus permukaan laut yang digunakan adalah data dalam rentang waktu 10 tahun. Data yang digunakan adalah data arus permukaan dari 1 Januari 1996 hingga 1 Januari 2016. Berdasarkan data yang diperoleh maka diketahui bahwa kecepatan arus permukaan maksimal yaitu $0.4 \mathrm{~m} / \mathrm{s}$ dan kecepatan arus maksimal terjadi pada bulan Januari di setiap tahunnya. Gambar 3 dibawah ini menampilkan data time series selama 10 tahun untuk arus permukaan pada daerah perairan yang melingkupi keempat alternatif lokasi STS transfer tersebut.
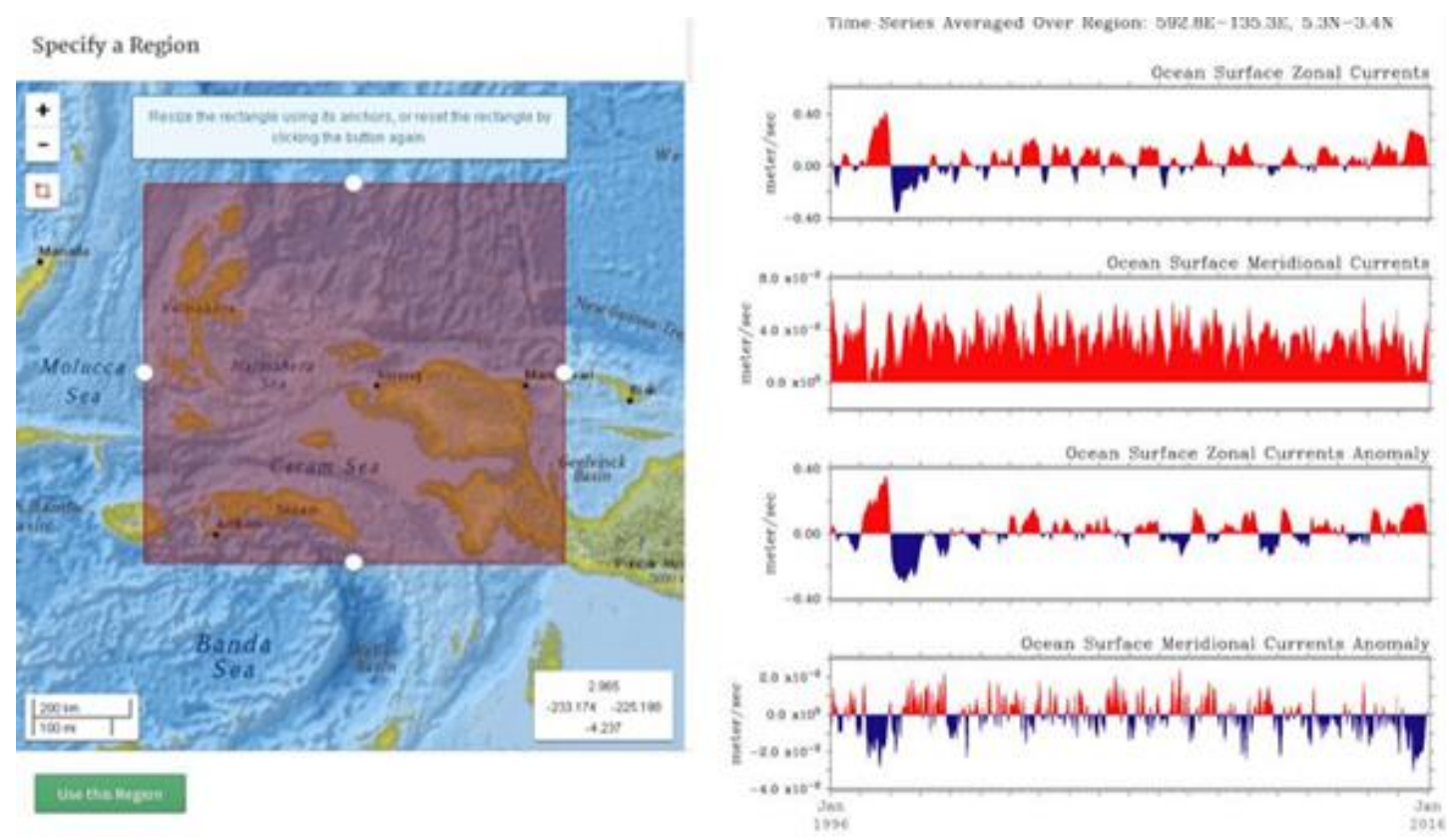

Gambar 3. Data time series arus permukaan pada perairan

\subsection{Kondisi Gelombang}

Data gelombang air laut didapatkan dari atmospheric model yang dikembangkan oleh The European Centre for MediumRange Weather Forecasts (ECMWF) [3]. Atmospheric model yang disimulasikan menggunakan data yang kurang lebih selama 3 periode tahun yaitu 1 Januari hingga 30 September 2015. Data yang digunakan meliputi; 10 meter winda data in $\mathrm{X}$ direction ( $\mathrm{U}$ wind component), 10 meter wind data in $\mathrm{x}$-direction ( $\mathrm{W}$ wind component), dan analysis ERA interim wave model yang didalamnya termasuk tinggi gelombang signifikan, arah gelombang rata-rata, dan rata-rata periode gelombang. Dari simulasi dengan menggunakan pemodelan tersebut didapatkan bahwa maksimum tinggi gelombang signifikan (H 1/3) adalah berkisar $1 \mathrm{~m}$. Gambar 4 berikut memperlihatkan distribusi tinggi gelombang signifikan (significant wave height distribution) untuk keempat alternatif lokasi STS LNG transfer. 


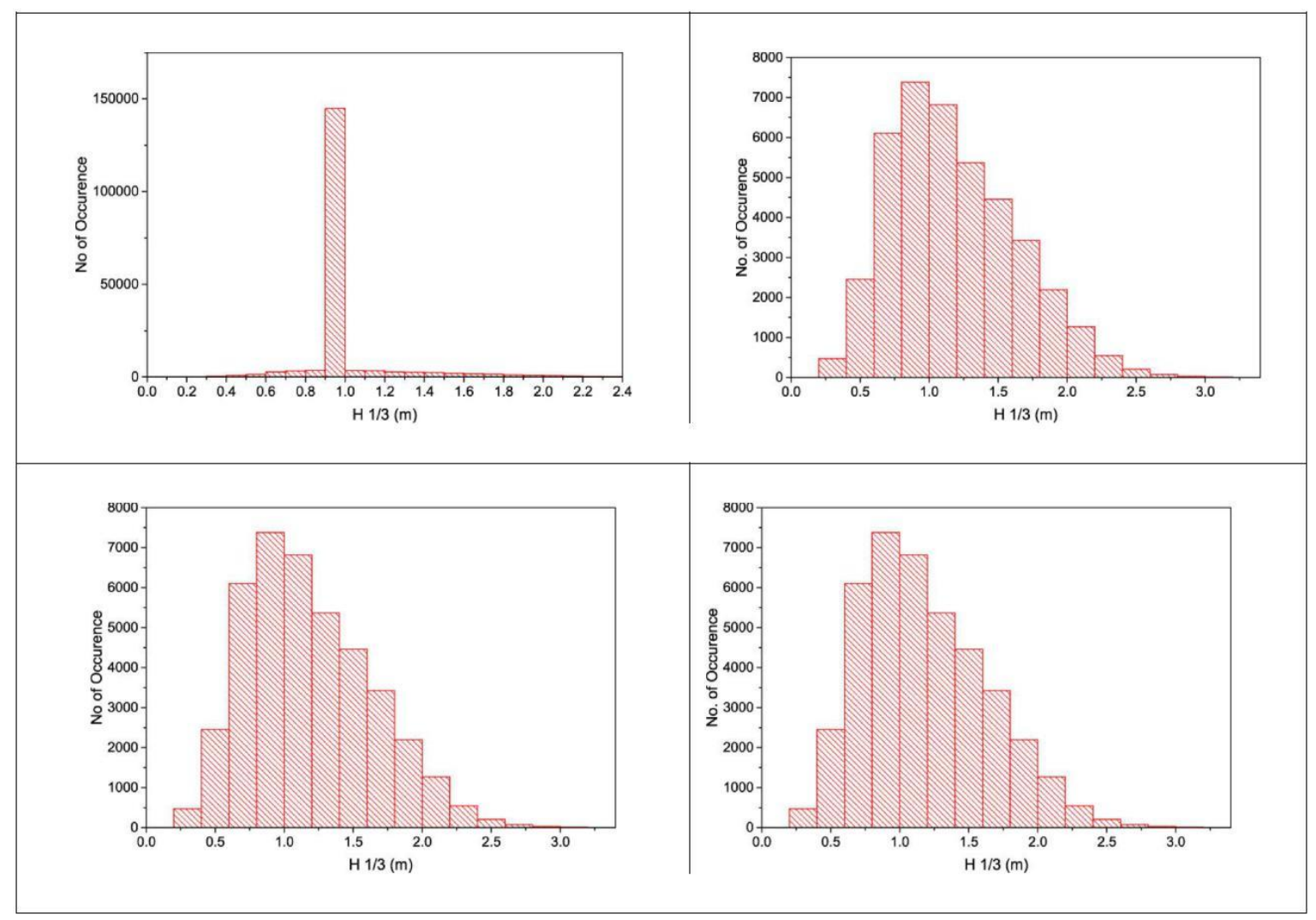

Gambar 4. Distibusi Tinggi Gelombang Signifikan pada Alternatif Lokasi STS LNG Transfer

\subsection{Fluktuasi Pasang Surut (Tidal Fluctuations)}

Data fluktuasi pasang surut didapatkan dari stasiun pengamatan cuaca realtime di BP Tangguh dan fasilitas pengamatan sea level di Ambon [4]. Dalam menentukan besaran pasang surut maka dilakukan dengan metode analisis pasang surut. Data yang disediakan oleh kedua lokasi pengamatan memiliki interval 1 jam. Data fluktuasi level air yang sudah dikumpulkan harus dianalisis dengan tujuan untuk memperoleh lebel air yang dirancang untuk tujuan skenario. Analisis yang lebih baik dan prediksi fluktuasi pasang surut merupakan salah satu aspek penting untuk menyediakan data desain tingkat air untuk kegiatan laut terkait apapun. Sedangkan prosedur untuk menganalisis pasang surut dengan menggunakan matematik memberikan prosedur matematika untuk melakukan analisis harmonik dari fluktuasi pasang surut dengan menggunakan teknik kuadrat terkecil. Hasil dari perhitungan dan prediksi pasang surut dapat dilihat pada Gambar 5
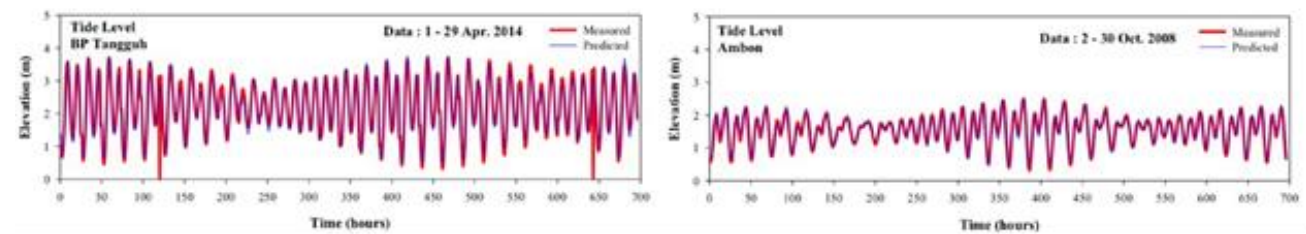

Gambar 5. Perhitungan dan Prediksi Fluktuasi Pasang Surut di Teluk Bintuni dan Ambon

\subsection{Rangkuman Analisa Pemilihan Lokasi STS LNG Transfer}

Data lingkungan yang digunakan pada studi ini sudah di kolaborasikan dengan berbagai macam data yang tersedia dan bersumber dari internet. Sangat penting diperhatikan bahwa analisis yang dilakukan hanya berdasarkan pada data sekunder yang diperolah dari beberapa sumber. Data yang lebih akurat dan memiliki ketetepan tinggi sangat diperlukan untuk mendapatkan hasil yang komprehensif. Berdasarkan input data yang diberikan, tabel berikut adalah hasil analisis pemilihan lokasi STS Transfer. Diperlihatkan bahwa Lokasi A (Fakfak) merupakan lokasi yang memenuhi seluruh kondisi lingkungan. 
Table 1 Rangkuman Pemlihan Lokasi STS LNG Transfer

\begin{tabular}{lccccc}
\hline LOCATION & \multicolumn{5}{c}{ ENVIRONMENTAL PARAMETER } \\
\hline & Bathymetric & Current & Wave & Tide & Geological \\
\hline Fakfak & OK & OK & OK & OK & OK \\
Manokwari & NG & OK & OK & OK & OK \\
Namlea & NG & OK & OK & OK & OK \\
Halmahera & NG & OK & OK & OK & OK \\
\hline Note : OK : Okay and without objection & & & & \\
NG : : Not Good but technically feasible & & & & \\
\hline
\end{tabular}

\section{PREDIKSI PERGERAKAN SIDE-BY-SIDE STS LNG TRANSFER}

Respon gerak orde dua untuk kondisi kapal side-by-side pada gelombang reguler dianalisa dengan menggunakan pendekatan 3D diffraction analysis melalui perangkat lunak MOSES. Adapun input data yang digunakan dalam analisa adalah data ukuran utama kapal, bentuk badan kapal (vessel geometry), massa dan momen inersia massa, hidrodinamika, dan arah dari gelombang terhadap badan kapal. Dikarenakan pada saat STS kapal dioperasikan dalam kondisi stasioner, maka kecepatan maju kapal (advance speed) adalah nol. Pada simulasi, bentuk lambung kapal dibagi menjadi beberapa panel untuk mendapatkan prediksi yang lebih akurat. Output dari analisa adalah amplitudo dan pergerakan relatif dari enam derajat kebebasan (6 degree of freedom (DOF)) yaitu: surge, sway, have, roll, pitch, dan yaw sebagai fungsi dari frekuensi gelombang atau periode gelombang. Tabel 2 memperlihatkan data LNG vessel $\left(155.000 \mathrm{~m}^{3}\right)$ dan shuttle LNG vessel $\left(3000 \mathrm{~m}^{3}\right) \mathrm{yang}$ digunakan dalam STS Transfer.

Table 2 Ukuran Utama LNG Vessel dan Shuttel LNG Vessel

\begin{tabular}{|c|c|c|}
\hline Designation and Symbol & LNG Vessel & Shuttle LNG \\
\hline Length between perpendiculars, (Lpp) & $285 \mathrm{~m}$ & $81 \mathrm{~m}$ \\
\hline Breadth, (B) & $43 \mathrm{~m}$ & $15 \mathrm{~m}$ \\
\hline Depth (D) & $26 \mathrm{~m}$ & $7 \mathrm{~m}$ \\
\hline Draft, $(\mathrm{T})$ & $18 \mathrm{~m}$ & $5 \mathrm{~m}$ \\
\hline Displacement, $(\Delta)$ & ton & ton \\
\hline Cargo Capacity & $155,000 \mathrm{~m}^{3}$ & $3,000 \mathrm{~m}^{3}$ \\
\hline Roll Radius Gyration (Kxx) & $14.3 \mathrm{~m}$ & $5 \mathrm{~m}$ \\
\hline Pitch Radius Gyration (Kyy) & $71.25 \mathrm{~m}$ & $20.25 \mathrm{~m}$ \\
\hline Yaw Radius Gyration (Kzz) & $71.25 \mathrm{~m}$ & $20.5 \mathrm{~m}$ \\
\hline Keel to Gravity (KG) & $13 \mathrm{~m}$ & $7 \mathrm{~m}$ \\
\hline \multicolumn{3}{|l|}{ Manifold Location: } \\
\hline - from FP & $140 \mathrm{~m}$ & $70 \mathrm{~m}$ \\
\hline - from keel & $27 \mathrm{~m}$ & $8 \mathrm{~m}$ \\
\hline - from CL & $21.5 \mathrm{~m}$ & $7.5 \mathrm{~m}$ \\
\hline
\end{tabular}

\subsection{Simulasi Numerik}

Karakteristik pergerakan dari LNG vessel dan shuttle LNG vessel pada gelombang reguler diprediksi dengan menggunakan metode 3d diffraction. Dalam analisa, bentuk badan kapal dimodelkan secara penuh melalui fine mesh dengan panel-panel yang merepresentasikan bentuk dari lambung kapal. Posisi side-by-side untuk kedua kapal yang menjadi objek studi dapat dilihat pada Gambar 6. Posisi manifold dari shuttle LNG terhadap manifold LNG vessel adalah berjarak secara horisontal sejauh $2 \mathrm{~m}$ dan $6 \mathrm{~m}$ secara vertikal. Posisi manifold antara kedua kapal diperlihatkan pada Gambar 7. LNG vessel diposisikan dengan mooring anchor di permukaan perairan yang memiliki kedalaman $50 \mathrm{~m}$. Panjang rantai jangkar sekitar $120 \mathrm{~m}$ yang diposisikan tegak lurus terhadap lambung kapal dan tegangan dari rantai jangkar adalah $80 \mathrm{~m}$-ton. Side-by-side mooring system terdiri dari 2 mooring line yang identik dimana setiap mooring line dihubungkan dengan tali nylon yang memiliki panjang $27 \mathrm{~m}$. 


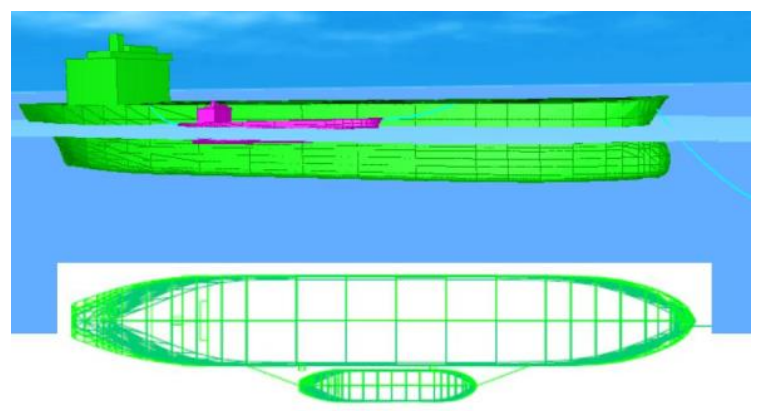

Gambar 6. Mesh generation dari LNG Vessel

Secara umum empat flexible hoses diperlukan untuk STS, tiga flexible hose digunakan untuk memuat LNG ke shuttle vessel dan satu flexible hose digunakan untuk mengembalikan uap dari LNG yang dihasilkan selama proses transfer. Nilai dari motion envelope sebagai dasar pertimbangan untuk menentukan keselamatan operasi saat STS transfer diperkenalkan oleh Van der Valk (2004). Adapun motion envelope tersebut adalah (i) pergerakan relatif frekuensi rendah horisontal (low frequency horizontal relative motion): $\pm 4 \mathrm{~m}$, (ii) pergerakan relatif frekuensi gelombang horisontal (wave frequency horizontal relative motion): $\pm 2 \mathrm{~m}$, dan (iii) peregrakan vertikal relatif: $\pm 2 \mathrm{~m}$. Kim et al (2003) memberikan kritera pergerakan relatif diantaranya adalah: (i) kriteria pergerakan relatif lateral adalah $1,7 \mathrm{~m}$, (ii) kriteria pergerakan relatif vertikal adalah 2.0 $\mathrm{m}$, dan (iii) kriteria percepatan relatif vertikal dan lateral adalah $0.5 \mathrm{~m} / \mathrm{s}^{2}$. Namun produsen flexible hose menyatakan baha secara teknis batasan operasi (operating envelope) dari flexible hose dapat lebih besar dari nilai yang disampaikan sebelumnya.

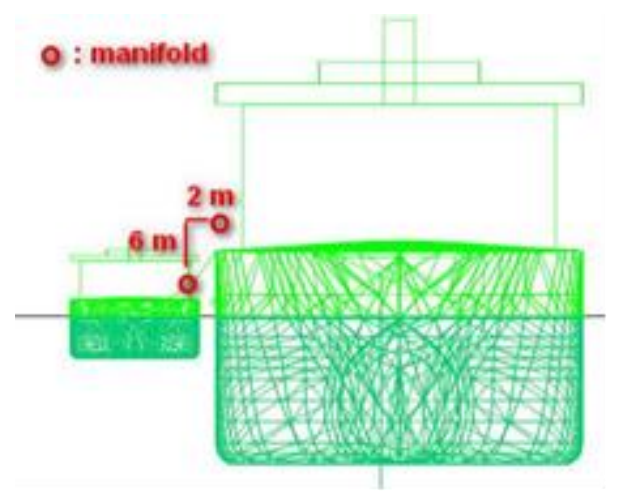

Gambar 7. Lokasi manifold antara dua kapal

Pada simulasi, pergerakan relatif kapal yang bergerak side-by-side diprediksi berdasarkan arah gelombang terhadap badan kapal (wave heading). Lima sudut dari wave heading, $\propto$, yang relatif terhadap kapal digunakan dalam simulasi seperti terlihat pada Gambar 8 dibawah ini. Adapun kelima wave heading ini adalah: $90^{0}$ beam on suttle vessel side (Kasus 1$)$, $135^{0}$ quartering on shuttle vessel side (Kasus 2), $180^{\circ}$ head on vessels (Kasus 3), $225^{0}$ quartering on mother vessel side (Kasus 4 ), dan $270^{\circ}$ beam on mother vessel side (Kasus 5).

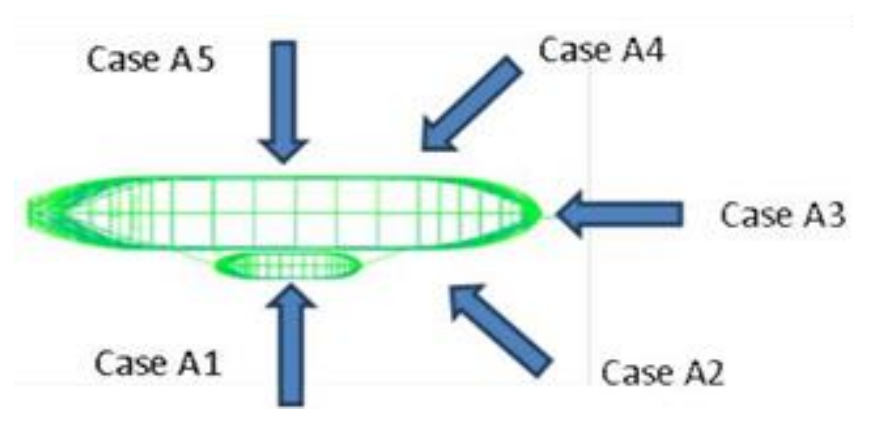

Gambar 8. Lima kasus arah gelombang terhadap badan kapal

Pada seluruh kasus tinggi gelombang signifikan sebesar $1 \mathrm{~m}, 2 \mathrm{~m}$, dan $3 \mathrm{~m}$ serta periode gelombang selama 6 detik, 8 detik, dan 10 detik digunakan dalam simulasi. Simulasi hanya menghitung pergerakan relatif antara kedua kapal terhadap angin dan arus tertentu. Beban kerja aman (safe working load (SWL)) yang digunakan untuk beban yang diterima oleh tali tambat dan fender mengacu pada standar yang diberikan oleh OCIMF (1988 dan 1992). Side-by-side mooring pada umumnya dimungkinkan sampai dengan tinggi gelombang 2,5 $\mathrm{m}$ dan kecepatan angin sampai dengan 30 knot.

\subsection{Hasil Simulasi}


Hasil simulasi diberikan dalam bentuk root mean square (RMS) dari pergerakan vertikal (vertical motion), pergerakan relatif (relative motion), dan percepatan gerak (acceleration motion). Gambar 9 berikut ini memberikan nilai RMS dari pergerakan vertikal untuk shutlle LNG dan LNG vessel untuk seluruh kasus.

\begin{tabular}{|c|c|c|c|c|c|c|c|c|c|c|c|c|c|c|c|c|c|c|c|c|c|c|c|c|c|}
\hline \multicolumn{13}{|c|}{ CASES A1 (RMS Vertical Motion) } & \multicolumn{13}{|c|}{ CASES A2 (RMS Vertical Motion) } \\
\hline Wove height & & \multirow{2}{*}{$\begin{array}{c}{[\mathrm{m}]} \\
{[\mathrm{sec}]}\end{array}$} & \multicolumn{3}{|c|}{1} & \multicolumn{3}{|c|}{2} & \multicolumn{3}{|c|}{3} & & \multirow{2}{*}{$\begin{array}{l}\text { Wave } \\
\text { Ware }\end{array}$} & \multirow{2}{*}{$\begin{array}{l}\text { height } \\
\text { Period }\end{array}$} & & \multirow{2}{*}{$\begin{array}{l}{[\mathrm{m}]} \\
{[\mathrm{sec}]}\end{array}$} & \multicolumn{3}{|c|}{1} & \multicolumn{3}{|c|}{2} & \multicolumn{3}{|c|}{3} \\
\hline \multirow{2}{*}{ Wove Period } & & & 6 & 8 & 10 & 6 & 8 & 10 & 6 & 8 & 10 & & & & & & ] 6 & 8 & 10 & 6 & 8 & 10 & 6 & 8 & 10 \\
\hline & Heave & {$[\mathrm{m}]$} & 0.03 & 0.04 & 0.04 & 0.03 & 0.04 & 0.04 & 0.030 & 0.06 & 0.05 & & \multirow{3}{*}{\multicolumn{2}{|c|}{ Shuttle LNG }} & Heave & {$[\mathrm{m}]$} & 0.03 & 0.03 & 0.03 & 0.02 & 0.03 & 0.03 & 0.01 & 0.02 & 0.03 \\
\hline \multirow[t]{3}{*}{ Shuttle LNG } & Roll & [deg] & 0.49 & 0.48 & 0.47 & 0.53 & 0.51 & 0.48 & 1.930 & 0.60 & 0.48 & & & & Roll & [deg] & 0.45 & 0.45 & 0.46 & 0.40 & 0.45 & 0.47 & 0.33 & 0.43 & 0.48 \\
\hline & Pitch & [deg] & 0.08 & 0.07 & 0.08 & 0.06 & 0.05 & 0.06 & 0.760 & 0.09 & 0.04 & & & & Pitch & [deg] & 0.07 & 0.07 & 0.07 & 0.03 & 0.04 & 0.05 & 0.08 & 0.05 & 0.03 \\
\hline & Heave & {$[\mathrm{m}]$} & 0.00 & 0.00 & 0.00 & 0.01 & 0.01 & 0.01 & 0.010 & 0.01 & 0.01 & & \multirow{3}{*}{\multicolumn{2}{|c|}{ BP LNG }} & Heave & [m] & 0.00 & 0.00 & 0.00 & 0.01 & 0.01 & 0.01 & 0.02 & 0.02 & 0.01 \\
\hline \multirow[t]{2}{*}{ BP LNG } & Roll & [deg] & 0.13 & 0.14 & 0.14 & 0.29 & 0.30 & 0.56 & 0.560 & 0.55 & 0.54 & & & & Roll & [deg] & 0.13 & 0.13 & 0.13 & 0.27 & 0.27 & 0.25 & 0.45 & 0.47 & 0.44 \\
\hline & Pitch & [deg] & 0.00 & 0.00 & 0.00 & 0.00 & 0.00 & 0.00 & 0.000 & 0.00 & 0.00 & & & & Pitch & [deg] & 0.00 & 0.00 & 0.00 & 0.00 & 0.00 & 0.00 & 0.00 & 0.00 & 0.00 \\
\hline \multicolumn{13}{|c|}{ CASES A3 (RMS Vertical Motion) } & \multicolumn{13}{|c|}{ CASES A4 (RMS Vertical Motion) } \\
\hline \multirow{3}{*}{$\begin{array}{l}\text { Wave height } \\
\text { Wove Period }\end{array}$} & & [m] & \multicolumn{3}{|c|}{1} & \multicolumn{3}{|c|}{2} & \multicolumn{3}{|c|}{3} & & Wove & height & & [m] & & 1 & & & 2 & & & 3 & \\
\hline & & [sec] & 6 & 8 & 10 & 6 & 8 & 10 & 6 & 8 & 10 & & Wave & Period & & [sec] & 16 & 8 & 10 & 6 & 8 & 10 & 6 & 8 & 10 \\
\hline & Heave & {$[\mathrm{m}]$} & 0.03 & 0.03 & 0.03 & 0.02 & 0.02 & 0.03 & 0.000 & 0.01 & 0.02 & & & & Heave & [m] & 0.03 & 0.03 & 0.03 & 0.01 & 0.02 & 0.03 & 0.01 & 0.01 & 0.02 \\
\hline Shuttle LNG & Roll & [deg] & 0.47 & 0.45 & 0.47 & 0.43 & 0.45 & 0.46 & 0.370 & 0.44 & 0.45 & & Shuttl & Ie LNG & Roll & Ideg & 80.48 & 0.47 & 0.47 & 0.51 & 0.48 & 0.46 & 0.57 & 0.44 & 0.45 \\
\hline & Pitch & [deg] & 0.07 & 0.07 & 0.08 & 0.05 & 0.06 & 0.07 & 0.020 & 0.03 & 0.05 & & & & Pitch & [deg & 10.07 & 0.07 & 0.07 & 0.04 & 0.05 & 0.06 & 0.04 & 0.03 & 0.05 \\
\hline & Heave & {$[m]$} & 0.00 & 0.00 & 0.00 & 0.01 & 0.01 & 0.01 & 0.030 & 0.02 & 0.02 & & & & Heave & {$[m]$} & 0.00 & 0.00 & 0.00 & 0.01 & 0.01 & 0.01 & 0.02 & 0.02 & 0.02 \\
\hline BP LNG & Roll & [deg] & 0.08 & 0.09 & 0.09 & 0.09 & 0.09 & 0.09 & 0.100 & 0.09 & 0.09 & & & LNG & Roll & [deg & $5] 0.05$ & 0.05 & 0.05 & 0.10 & 0.10 & 0.08 & 0.03 & 0.09 & 0.09 \\
\hline & Pitch & [deg] & 0.00 & 0.00 & 0.00 & 0.00 & 0.00 & 0.00 & 0.010 & 0.01 & 0.00 & & & & Pitch & Ideg & 510.00 & 0.00 & 0.00 & 0.00 & 0.00 & 0.00 & 0.01 & 0.01 & 0.00 \\
\hline & & & & & & & & & CAS & SES A & $5(\mathrm{RN}$ & $15 \mathrm{Ve}$ & artical & Motio & & & & & & & & & & & \\
\hline & & & & & & Wave & height & & {$[m]$} & & 1 & & & 2 & & & 3 & & & & & & & & \\
\hline & & & & & & Ware & Petiod & & {$[\mathrm{sec}]$} & 6 & 8 & 10 & 6 & 8 & 10 & 6 & 8 & 10 & & & & & & & \\
\hline & & & & & & & & Heave & $=[\mathrm{m}]$ & 0.03 & 0.03 & 0.03 & 0.02 & 0.03 & 0.04 & 0.00 & 0.03 & 0.04 & & & & & & & \\
\hline & & & & & & Shuttl & $=$ LNG & Roll & [deg] & 0.45 & 0.46 & 0.47 & 0.39 & 0.42 & 0.45 & 0.30 & 0.36 & 0.45 & & & & & & & \\
\hline & & & & & & & & Pitch & [deg] & 0.07 & 0.08 & 0.08 & 0.05 & 0.06 & 0.07 & 0.02 & 0.03 & 0.04 & & & & & & & \\
\hline & & & & & & & & Heave & $=[\mathrm{m}]$ & 0.00 & 0.00 & 0.00 & 0.01 & 0.01 & 0.01 & 0.02 & 0.01 & 0.01 & & & & & & & \\
\hline & & & & & & & & Roll & [deg] & 0.04 & 0.04 & 0.04 & 0.12 & 0.13 & 0.12 & 0.36 & 0.38 & 0.37 & & & & & & & \\
\hline & & & & & & & & Pitch & [deg] & 0.00 & 0.00 & 0.00 & 0.00 & 0.00 & 0.00 & 0.00 & 0.01 & 0.00 & & & & & & & \\
\hline
\end{tabular}

Gambar 9. Pergerakan vertikal relatif untuk lima kasus arah gelombang terhadap badan kapal

Pergerakan vertikal yang dianalisa meliputi pergerakan heave, roll, dan pitch dimana letak titik gerak diukur pada manifold kapal. Gambar 9 memeperlihatkan respon gerak dari shuttle LNG lebih tinggi dibandingkan dengan LNG vessel untuk seluruh kasus simulasi. Peningkatan ketinggian gelombang akan memberikan pengaruh pada respon gerak untuk semua kasus dan kapal. Respon gerak tertinggi diberikan pada periode gelombang sebesar 6 detik untuk gerak roll kapal shuttle LNG pada Kasus 1 . Hal ini terjadi pada kondisi gelombang yang datang dari sisi kapal dengan tinggi gelombang $3 \mathrm{~m}$ dan periode 6 detik.

Gambar 10 memperlihatkan respon gerak relatif lateral kapal yang lebih tinggi dibandingkan dengan gerak longitudinal (longitudinal motion) dan gerak vertikal. Gerak relatif lateral dapat dikurangi dengan meningkatkan jumlah dan kekuatan mooring line yang menghubungkan antara shuttle LNG dengan LNG vessel. Untuk Kasus 1, repon longitudinal lebih tinggi dari gerak lateral dan vertikal dari kapal pada kondisi tinggi gelombang adlaah $3 \mathrm{~m}$ dan periode gelombang 6 detik.

Mangacu pada [5], RMS dari gerak lateral realtif lebih kecil dari kriteria desain pada seluruh arah gelombang namun lebih tinggi dari kriteria desain pada seluruh kasus jika mengacu pada kriteria yang diberikan oleh [6]. Fenomena inin terjadi karena mooring line yang menghubungkan LNG vessel dengan shuttle LNG terlalu lemah. RMS dari gerak relatif longitudinal juga lebih rendah dari kriteria desain pada seluruh kondisi arah gelombang kecuali pada Kasus 1 untuk tinggi gelombang 3 m dan periode gelombang 6 detik. RMS pada gerak relatif vertikal lebih kecil dibandingkan dengan kriteria desain untuk seluruh arah gelombang. Sama halnya dengan gerak realatif, RMS untuk gerak lateral, longitudinal, dan percepatan relatif vertikal lebih rendah dibandingkan dengan kriteria desain untuk seluruh arah gelombang. 


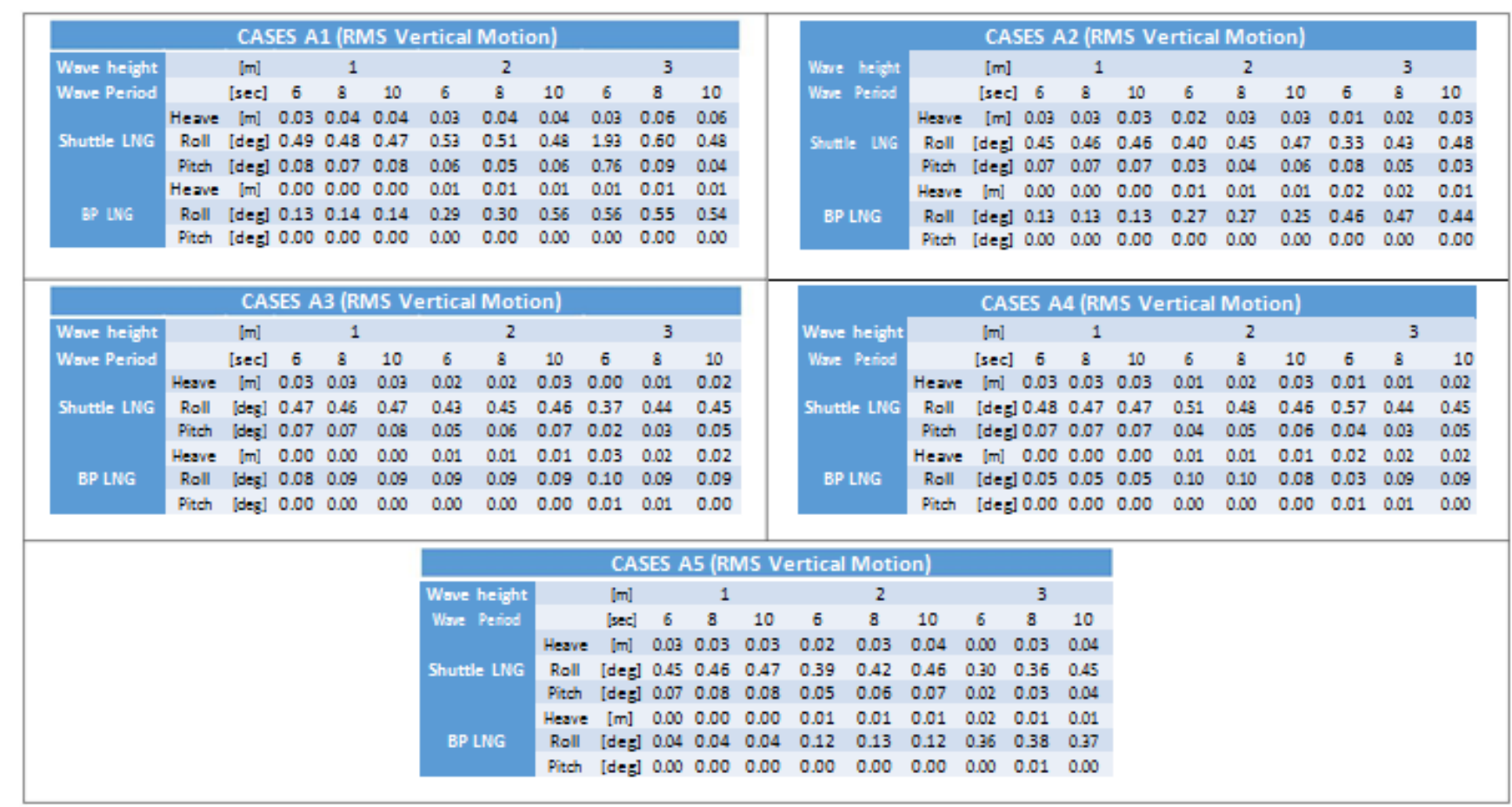

Gambar 10. Gerak relatif dan percepatan untuk lima kasus arah gelombang terhadap badan kapal

\section{KESIMPULAN}

Kajian STS LNG transfer telah dilakukan pada studi ini antara LNG vessel dengan shuttle LNG vessel. Kajian pemilihan lokasi STS transfer dilakukan pada empat alternatif lokasi STS LNG transfer diantaranya adalah Fakfak, Manokwari, Namlea, dan Halmahera. Berdasarkan kajian lingkungan yang dilakukan, Fakfak adalah lokasi yang terbaik untuk STS LNG transfer.

Hasil simulasi pada gerak yang diakibatkan oleh kondisi lingkungan, seperti angin, arus dan utamanya adalah tinggi, periode dan arah gelombang terhadap lambung kapal diperoleh bahwa STS transfer antara LNG vessel dan shuttle LNG vessel dapat dilakukan pada ketinggian gelombang maksimal adalah $2 \mathrm{~m}$. Berdasarkan kriteria dari gerak relatif dan percepatan, hampir semua kondisi berada pada daerah yang dapat diterima kecuali pada Kasus 1 dimana gelombang dengan ketinggian $3 \mathrm{~m}$ dan periode 6 detik mengarah ke sisi dari shuttle LNG.

\section{REFERENSI}

[1] P. M. E. N. 19 T. 2009, PERATURAN MENTERI ESDM NOMOR 19 TAHUN 2009, Tentang Kegiatan Usaha Gas Bumi Melalui Pipa. Indonesia.

[2] G. S. E. BONJEAN F. AND LAGERLOEF, "Diagnostic Model and Analysis of the Surface Currents in the Tropical Pacific Ocean,” J. Phys. Oceanogr., vol. 32, no. 10, pp. 2938-2954, 2002.

[3] “About|ECMWF." [Online]. Available: https://www.ecmwf.int/en/about.

[4] “SEA LEVEL STATION MONITORING FACILITY.” [Online]. Available: http://www.iocsealevelmonitoring.org/.

[5] C. A. C. V. D. E. A. VALK, "Chiksan LNG Marine Loading Arm Enhanced for Application in Exposed Areas," in LNG-14 Conference, 2004.

[6] B. W. KIM, M. S. , HA, M. K. HA, AND KIM, "Relative Motions between LNG-FPSO and Side-by-Side positioned LNG Carrier in Waves," HSC-05, 2003. 